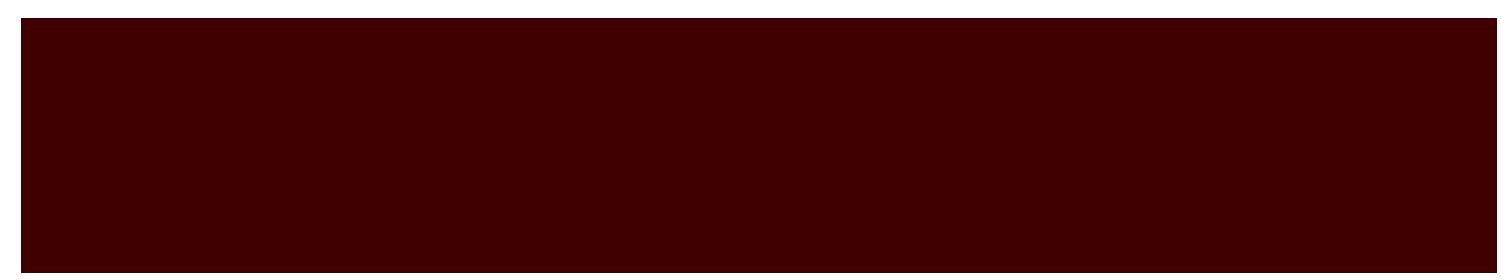

\title{
Insights into the Soluble PEG-Supported Synthesis of Cytosine-Containing Nucleoside 5'-Mono-, Di-, and Triphosphates
}

\author{
Céline Crauste, Christian Périgaud, and Suzanne Peyrottes* \\ UMR 5247 CNRS-UM1-UM2, Institut des Biomolécules Max Mousseron (IBMM), Nucleosides and \\ Phosphorylated Effectors Team, Université Montpellier 2, cc1705, Place E. Bataillon, \\ 34095 Montpellier, France
}

suzanne.peyrottes@univ-montp2.fr;peyrottes@univ-montp2.fr

Received September 7, 2009

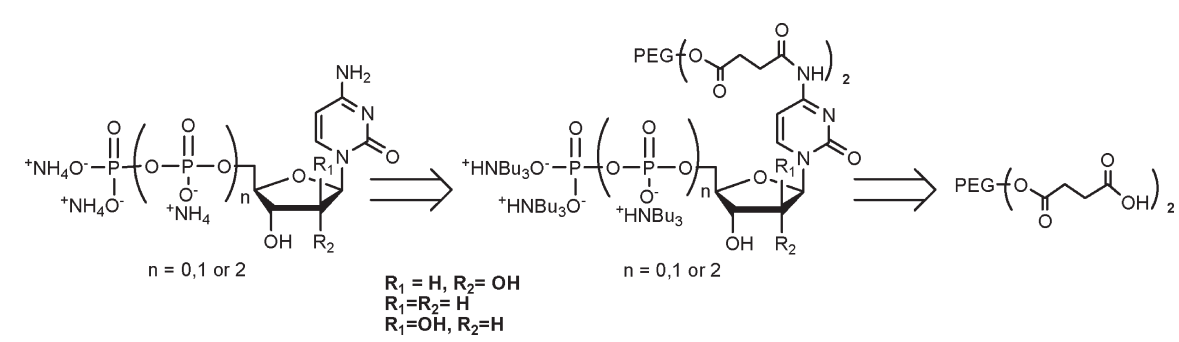

Nucleoside phosphoesters (nucleotides) have crucial roles in a large variety of biological processes including nucleic acid biosynthesis and their corresponding analogues are extensively used as biological tools. Herein, we describe a new and efficient synthetic procedure involving polyethylene glycol (PEG) as soluble support and regioselective mono-, di-, and triphosphorylation steps. Applied to natural and synthetic cytosine containing nucleosides, this methodology allowed the preparation of various phosphorylated forms in high yields and good purity.

\section{Introduction}

Nucleotides, especially nucleoside 5'-phosphorylated forms, are involved in many fundamental biological processes and pathways, ${ }^{1}$ and constitute an important area of research. Thus, several procedures have been reported for the conversion of a nucleoside to its corresponding 5'-mono-, di-, or triphosphorylated forms, using classical solution synthesis. ${ }^{2}$ The phosphorylation success depends considerably on the nature of the substrate and to date no protocol for making nucleoside $5^{\prime}$-triphosphates is universally satisfactory. Moreover, solution methods usually yield to complex crude mixtures which require tedious purification steps involving first ion-exchange chromatography on DEAE-Sephadex in aqueous buffers. In addition to the desired nucleotides, the crude mixture also contains large amounts of inorganic salts, such as inorganic phosphates, that may be eliminated by an additional purification step by using preparative C18 reverse-phase HPLC. Usually, this fastidious and long purification procedure, associated with the relative low chemical stability of these derivatives, induces a decrease in yields.

(1) Williams, D. M.; , Blackburn, G. M., Nucleic acid chemistry and biology; Royal Society of Chemistry: Letchworth, UK, 2007.

(2) Burgess, K.; Cook, D. Chem. Rev. 2000, 100, 2047-2059.
Since Merrifield et al. ${ }^{3}$ introduced the use of polymersupported synthesis of oligopeptides, insoluble supports have become an important tool for organic synthesis, ${ }^{4}$ especially for the synthesis of biopolymers, 5,6 such as oligonucleotides, peptides, and carbohydrates. Few works have been reported on the supported synthesis of nucleoside triphosphates, ${ }^{7-18}$ with the aim of reaching completion of

(3) Merrifield, R. B. J. Am. Chem. Soc. 1963, 85, 2149-2154

(4) Dörwald, F. Z. Organic synthesis on solid phase; Wiley-VCH: New York, 2000

(5) Seeberger, P. H.; Haase, W. C. Chem. Rev. 2000, 100, 4349-4394.

(6) Venkatesan, N.; Kim, B. H. Chem. Rev. 2006, 106, 3712-3761.

(7) Ahmadibeni, Y.; Parang, K. Org. Lett. 2005, 7, 5589-5592.

(8) Ahmadibeni, Y.; Parang, K. Org. Lett. 2005, 7, 1955-1958.

(9) Ahmadibeni, Y.; Parang, K. J. Org. Chem. 2005, 70, 1100-1103.

(10) Ahmadibeni, Y.; Parang, K. J. Org. Chem. 2006, 71, 5837-5839.

(11) Ahmadibeni, Y.; Parang, K. J. Org. Chem. 2006, 71, 6693-6696.

(12) Ahmadibeni, Y.; Parang, K. Org. Lett. 2007, 9, 4483-4486.

(13) Ahmadibeni, Y.; Parang, K. Angew. Chem., Int Ed. 2007, 46, 47394743 .

(14) Bradley, M.; , Bruckler, C. WO 2007/110624 A2, 2007.

(15) Brownlee, G. G.; Fodor, E.; Pritlove, D. C.; Gould, K. G.; Dalluge, J. J. Nucleic Acids Res. 1995, 23, 2641-2647.

(16) Gaur, R. K.; Sproat, B. S.; Krupp, G. Tetrahedron Lett. 1992, 33, 3301-3304.

(17) Lebedev, A. V.; Koukhareva, T. II; Beck, M. M. V. Nucleosides, Nucleotides, Nucleic Acids 2001, 20, 1403-1409.

(18) Schoetzau, T.; Holletz, T.; Cech, D. Chem. Commun. 1996, 387-388. 
the reaction (use of excess reagent) and to greatly simplify purification processes. These works were based on the use of the phosphoramidite chemistry and among these, only Parang et al. ${ }^{7-13}$ have developed a regioselective method for nucleoside $5^{\prime}$-phosphates and $5^{\prime}$-thio-phosphates synthesis. Thus, the use of a new phosphorylation reagent immobilized on solid support allowed the desired derivatives to be isolated in good yields $(\sim 80 \%)$ and acceptable HPLC purity $(70-90 \%)$.

Despite the benefits offered by the solid phase approach, the heterogeneous reaction conditions (due to the nature of the insoluble polymers) often induce other problems such as nonlinear reaction kinetics, unequal distribution and/or access to the reaction sites, solvation problems, inefficient coupling rates, and difficulties for intermediates analysis. The search for alternative methodologies, aiming to restore homogeneous reaction conditions, has led to the development of soluble polymer supports. These last have received considerable attention because such a "liquid phase" synthesis retains many of the conventional solution chemistry advantages (high reactivity, lack of diffusion, and easy analysis) while still allowing a smooth isolation and purification of the product. ${ }^{19,20}$

In addition, soluble polymers are usually much less expensive than insoluble ones. As an example, soluble polyethylene glycol (PEG), polyvinyl alcohol, and other polymers have been successfully used for the synthesis of bio-oligomers (peptides, ${ }^{21,22}$ oligonucleotides, ${ }^{23,24}$ polysaccharides) ${ }^{25}$ and small molecules. ${ }^{19}$ More recently fluorous phase $^{26-28}$ and ionic liquids ${ }^{29-35}$ have also been reported as useful soluble supports for organic synthesis and olignucleotide preparation. ${ }^{36,37}$

Among these soluble polymer supports, PEG has been wildly used for the liquid-phase oligonucleotide synthesis. ${ }^{38}$

(19) Gravert, D. J · Janda, K. D. Chem, Rev. 1997, 97, 489-509.

(20) Toy, P. H.; Janda, K. D. Acc. Chem. Res. 2000, 33, 546-554

(21) Mutter, M.; Bayer, E. Angew. Chem., Int. Ed. Engl. 1974, 13, 88-89.

(22) Mutter, M.; Hagenmaier, H.; Bayer, E. Angew. Chem., Int. Ed. Engl. 1971, 10, 811-812.

(23) Cramer, F.; Helbig, R.; Hettler, H.; Scheit, K. H.; Seliger, H. Angew. Chem., Int. Ed. Engl. 1966, 5, 601.

(24) Hayatsu, H.; Khorana, H. G. J. Am. Chem. Soc. 1966, 88, 31823183 .

(25) Guthrie, R. D.; Jenkins, A. D.; Stehlice, J J. Chem. Soc. C 1971, 2690-2696.

(26) Curran, D. P. Med. Res. Rev. 1999, 19, 432-438.

(27) Miura, T.; Goto, K. T.; Hosaka, D.; Inazu, T. Angew. Chem., Int. Ed. 2003, 42, 2047-2051.

(28) Mizuno, M.; Goto, K.; Miura, T.; Matsuura, T.; Inazu, T. Tetrahedron Lett. 2004, 45, 3425-3428.

(29) Chan, T. H.; Damha, M. J.; Miao, W.; Donga, R. A.; He, X. WO 2006096963, 2006.

(30) Fraga-Dubreuil, J.; Bazureau, J. P. Tetrahedron Lett. 2001, 42, 6097 6100 .

(31) He, X.; Chan, T. H. Org. Lett. 2007, 9, 2681-2684.

(32) Huang, J. Y.; Lei, M.; Wang, Y. G. Tetrahedron Lett. 2006, 47, 3047 3050 .

(33) Miao, W.; Chan, T. H. Acc. Chem. Res. 2006, 39, 897-908.

(34) Miao, W. S.; Chan, T. H. J. Org. Chem. 2005, 70, 3251-3255.

(35) Vaultier, M.; Roche, C.; Gmouh, S.; Commercon, A. WO $2008003836,2006$.

(36) Donga, R. A.; Khaliq-Uz-Zaman, S. M.; Chan, T. H.; Damha, M. J. J. Org. Chem. 2006, 71, 7907-7910.

(37) Wada, T.; Narita, R.; Kato, Y.; Saigo, K. WO $2005070859,2005$. (38) Kitamura, A.; Horie, Y.; Uchida, T.; Yoshida, T. US 6380378, 1999.

(39) Bonora, G. M. Appl. Biochem. Biotechnol. 1995, 54, 3-17.

(40) Bonora, G. M.; Biancotto, G.; Maffini, M.; Scremin, C. L. Nucleic Acids Res. 1993, 21, 1213-1217.

(41) Bonora, G. M.; Ivanova, E.; Zarytova, V.; Burcovich, B.; Veronese, F. M. Bioconjugate Chem. 1997, 8, 793-797.
Borona et al. ${ }^{39-47}$ have developed a high-efficiency liquid phase (HELP) method for large-scale synthesis of oligonucleotides based on a PEG strategy; to date these works have not been adapted for nucleotide (nucleoside mono-, di-, and triphosphates) preparation. Thus, to develop a new nucleotide synthetic approach and to easily transfer the traditional solution-phase conditions to a supported methodology, we propose herein a new technology based on the use of a soluble PEG support.

\section{Results and Discussion}

Supported Nucleotide Synthesis: Polyethylene Glycol (PEG). The wide application of PEG in organic synthesis is closely related to its broad solubility profile. It is soluble in $N, N$-dimethylformamide (DMF), dichloromethane, toluene, acetonitrile, water, and methanol, but insoluble in diethyl ether, tert-butyl methyl ether, isopropyl alcohol, and cold methanol. Therefore, excess reagents and some byproduct could readily be eliminated at the end of each reaction step by using a simple precipitation from diethyl ether of the polymer-substrate followed up by filtration, and eventually additional purification by flash chromatography may be performed. A commercially available PEG of 4000 Da average molecular weight was selected as the starting material. Analyses of each supported intermediates were performed by nuclear magnetic resonance spectra $\left({ }^{1} \mathrm{H},{ }^{13} \mathrm{C}\right.$, and ${ }^{31} \mathrm{P}$ NMR).

Functionalization of PEG and Coupling Step. The synthetic strategy is based on PEG anchored to the nucleoside (nucleobase) through a basolabile linker. This procedure was selected to develop a synthetic method suitable for the preparation of nucleotide modified on the glycosidic moiety; indeed such a modification is often encountered within nucleoside analogues with antiviral and antitumoral properties. Thus, we focused on the synthesis of nucleotides containing cytosine as nucleobase namely cytidine (C), 2 -deoxycytidine $(\mathrm{dC})$, and cytarabine (araC, $1-\beta$-D-arabinofuranosylcytosine), a nucleoside analogue commonly used as an antitumoral agent in the treatment of acute myelogenous leukemia. ${ }^{48,49}$ Initial functionalization of PEG support with the basolabile linker was performed through the coupling of PEG- $(\mathrm{OH})_{2}$ with succinic anhydride in the presence of a catalytic amount of 4-dimethylaminopyridine (DMAP) in pyridine. $^{45} \mathrm{~A}$ quantitative rate of fonctionalization was estimated by ${ }^{13} \mathrm{C}$ NMR analysis by observing the shifts of $\mathrm{CH}_{2} \alpha$ and $\mathrm{CH}_{2} \beta$ PEG signals (Figure 1).

Then, the anchoring of $\mathrm{C}, \mathrm{dC}$, and araC was performed as follows. Each nucleoside was linked to the PEG-(Osuccinate $)_{2} 1$ through the exocyclic amino group of the

(42) Bonora, G. M.; Scremin, C. L.; Colonna, F. P.; Garbesi, A. Nucleic Acids Res. 1990, 18, 3155-3159.

(43) Bonora, G. M.; Scremin, C. L.; Colonna, F. P.; Garbesi, A. Nucleosides, Nucleotides 1991, 10, 269-273.

(44) Colonna, F. P.; Scremin, C. L.; Bonora, G. M. Tetrahedron Lett. 1991, 32, 3251-3254.

(45) Denapoli, L.; Messere, A.; Montesarchio, D.; Piccialli, G.; Santacroce, C.; Bonora, G. M. Nucleosides, Nucleotides 1993, 12, 21-30.

(46) Scremin, C. L.; Bonora, G. M. Tetrahedron Lett. 1993, 34, 46634666.

(47) Zaramella, S.; Bonora, G. M. Nucleosides, Nucleotides 1995, 14, 809812.

(48) Jordheim, L. P.; Galmarini, C. M.; Dumontet, C. Bull. Cancer 2005, 92, 239-248.

(49) Talley, R. W.; Vaitkevicius, V. K. Blood 1963, 21, 352-362. 
Crauste et al.

\section{SCHEME $1^{a}$}
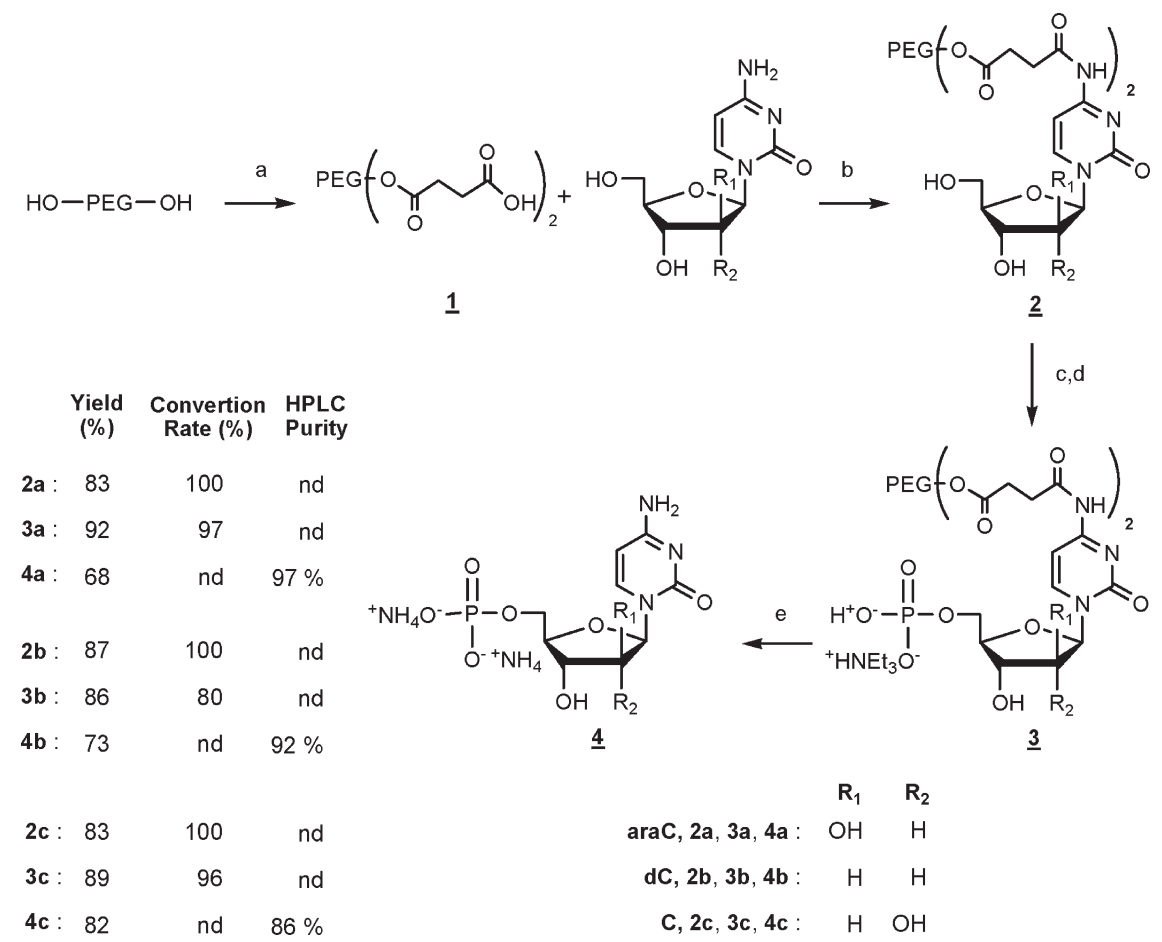

${ }^{a}$ Reagents and conditions: (a) succinic anhydride, DMAP, pyridine, rt, 2 days, $86 \%$; (b) DCC, $\mathrm{HOBT}, \mathrm{CH}_{2} \mathrm{Cl}_{2}, \mathrm{DMF}^{\circ} 60{ }^{\circ} \mathrm{C}, 6 \mathrm{~h}$; (c) $\mathrm{POCl}{ }_{3}$, $\mathrm{PO}(\mathrm{OEt})_{3} / 35^{\circ} \mathrm{C}$ or $\mathrm{CH}_{3} \mathrm{CN} / 0{ }^{\circ} \mathrm{C}, 1 \mathrm{~h}$; (d) TEAB $1 \mathrm{M}, \mathrm{pH} 7.5$; (e) $\mathrm{NH}_{4} \mathrm{OH}_{\mathrm{c}}$, rt, 1 h.

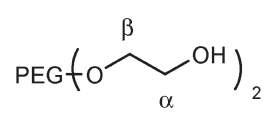<smiles>CC(C)(C)OCCOC(=O)CCCC(=O)O</smiles>
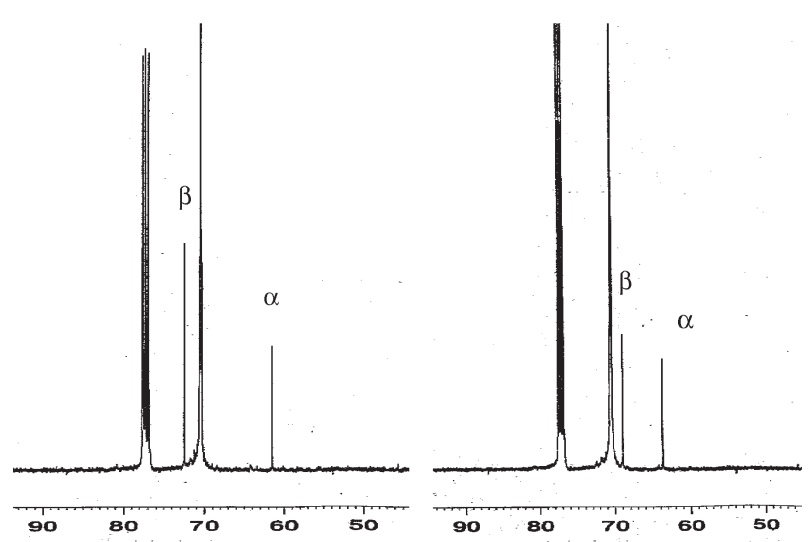

FIGURE 1. Determination of PEG functionalization with succinyl linker by ${ }^{13} \mathrm{C}$ NMR (100 MHz) analysis: (left) starting PEG- $(\mathrm{OH})_{2}{ }^{13} \mathrm{C}$ NMR spectrum $\left(\mathrm{CDCl}_{3}\right)$ with $\delta 61.5 \mathrm{ppm}$ for $\mathrm{CH}_{2} \alpha$ and $\delta 72.8 \mathrm{ppm}$ for $\mathrm{CH}_{2} \beta$; (right) PEG-(O-succinate) ${ }_{2}{ }^{13} \mathrm{C}$ NMR spectrum $\left(\mathrm{CDCl}_{3}\right)$ with $\delta 64.2 \mathrm{ppm}$ for $\mathrm{CH}_{2} \alpha$ and $\delta 68.9 \mathrm{ppm}$ for $\mathrm{CH}_{2} \beta$.

nucleobase in the presence of 1-hydroxybenzotriazole (HOBT) and $N, N^{\prime}$-dicyclohexylcarbodiimide (DCC) as coupling agents in a mixture of anhydrous dichloromethane and DMF (Scheme 1). ${ }^{50}$ This protocol allowed anchoring regioselectively the selected nucleoside onto the polymer without

(50) Guo, Z. W.; Gallo, J. M. J. Org. Chem. 1999, 64, 8319-8322.

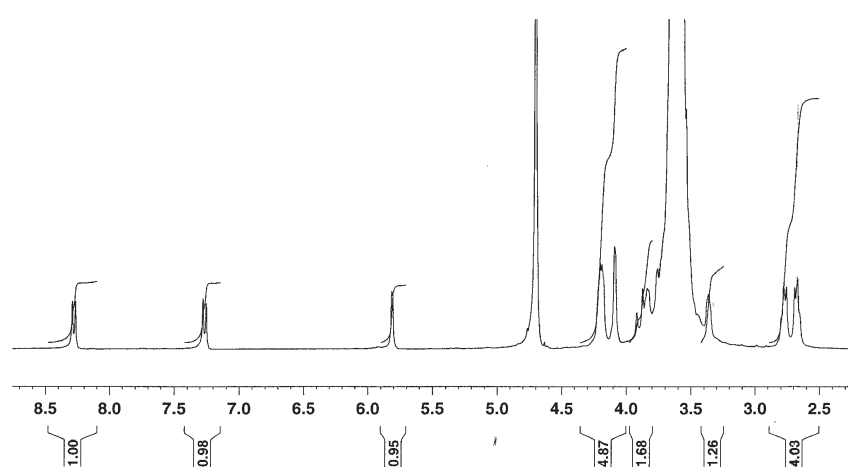

FIGURE 2. ${ }^{1} \mathrm{H}$ NMR $(300 \mathrm{MHz})$ spectrum of PEG-C $\left(\mathrm{D}_{2} \mathrm{O}\right)$.

prior protection of the sugar hydroxyl functions. The PEGnucleosides $\mathbf{2} \mathbf{a}, \mathbf{2 b}$, and $\mathbf{2 c}$ were unequivocally characterized by ${ }^{1} \mathrm{H}$ NMR spectroscopy, which also confirms the complete removal of reagents (first ascertained by TLC). Coupling rates were estimated by comparing ${ }^{1} \mathrm{H}$ NMR integration of both signals of the $\mathrm{H}_{6}$ from the nucleobase and of the methylene groups of the succinyl linker (Figure 2). Conversions were quantitative and yields were between $83 \%$ and $87 \%$. With one nucleoside at each end of the polymeric chain, the capacity of the synthesized PEG-nucleoside was evaluated to be $0.5 \mathrm{mmol} \cdot \mathrm{g}^{-1}$.

Monophosphorylation Step. In a preliminary set of experiments, the monophosphorylation reaction was optimized with araC as nucleosidic model. To prepare nucleoside

(51) Gouy, M. H.; Fabre, H.; Blanchin, M. D.; Peyrottes, S.; Perigaud, C.; Lefebvre, I. Anal. Chim. Acta 2006, 566, 178-184. 
TABLE 1. Optimization of Supported araC Monophosphorylation Step

\begin{tabular}{|c|c|c|c|c|c|}
\hline entry & equiv of $\mathrm{POCl}_{3}$ & time $(\mathrm{h})$ & solvent/temp $\left({ }^{\circ} \mathrm{C}\right)$ & \multicolumn{2}{|c|}{$\% \mathrm{HPLC}^{a}$ araC/araCMP } \\
\hline 1 & 10 & 6 & $\mathrm{CH}_{3} \mathrm{CN} / 0$ & 53 & 47 \\
\hline 2 & 20 & 3 & $\mathrm{CH}_{3} \mathrm{CN} / 0$ & 31 & 69 \\
\hline 3 & 30 & 3 & $\mathrm{CH}_{3} \mathrm{CN} / 0$ & 24 & 76 \\
\hline 4 & 50 & 3 & $\mathrm{CH}_{3} \mathrm{CN} / 0$ & 18 & 82 \\
\hline 5 & 5 & 1 & $\mathrm{PO}(\mathrm{OEt})_{3} / 35-40$ & 57 & 43 \\
\hline 6 & 5 & 3 & $\mathrm{PO}(\mathrm{OEt})_{3} / 35-40$ & 69 & 31 \\
\hline 7 & 5 & 6 & $\mathrm{PO}(\mathrm{OEt})_{3} / 35-40$ & 69 & 31 \\
\hline 8 & 10 & 1 & $\mathrm{PO}(\mathrm{OEt})_{3} / 35-40$ & 15 & 85 \\
\hline 9 & 10 & 3 & $\mathrm{PO}(\mathrm{OEt})_{3} / 35-40$ & 14 & 86 \\
\hline 10 & 10 & 6 & $\mathrm{PO}(\mathrm{OEt})_{3} / 35-40$ & 11 & 89 \\
\hline 11 & 15 & 1 & $\mathrm{PO}(\mathrm{OEt})_{3} / 35-40$ & 3 & 97 \\
\hline 12 & 15 & 3 & $\mathrm{PO}(\mathrm{OEt})_{3} / 35-40$ & 9 & 91 \\
\hline 13 & 15 & 6 & $\mathrm{PO}(\mathrm{OEt})_{3} / 35-40$ & 7 & 93 \\
\hline
\end{tabular}

${ }^{a}$ Determined by HPLC ${ }^{51}$ after cleavage of the linker in between the support and the nucleot(s)ide.

h: PEG-nucleoside

H-6 h-6

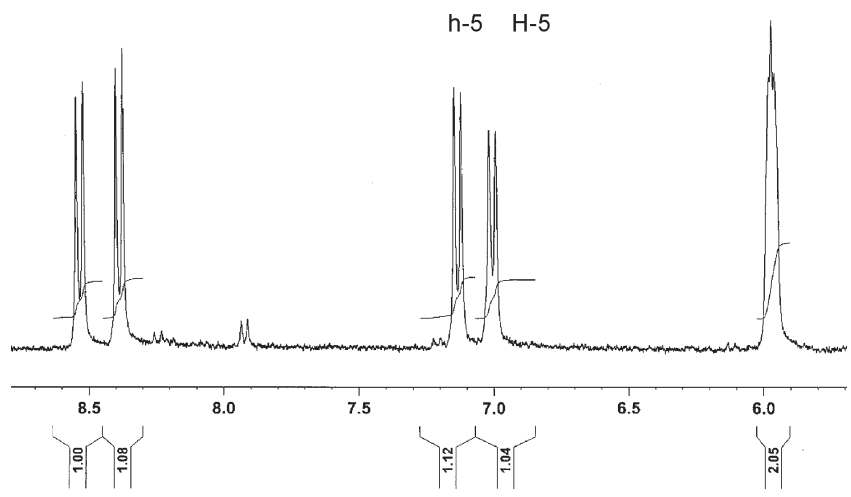

FIGURE 3. Determination of monophosphorylation rate by ${ }^{1} \mathrm{H}$ NMR analysis: ${ }^{1} \mathrm{H}$ NMR $\left(300 \mathrm{MHz}\right.$, in $\left.\mathrm{D}_{2} \mathrm{O}\right)$ spectrum obtained after monophosphorylation of PEG-araC in experimental conditions corresponding to entry 1 , Table 1 .

$5^{\prime}$-monophosphates the regioselective method of Yoshikawa et al., ${ }^{52,53}$ previously described for solution synthesis, was adapted. As conventional monophosphorylation of unprotected nucleosides requires the use of trialkylphosphate as solvent and phosphorus oxychloride as phosphorylating agent, an initial attempt was carried out in these conditions. Unfortunately, PEG-araC 2a was soluble at neither $0{ }^{\circ} \mathrm{C}$ nor room temperature in triethylphosphate. The solubility of the PEGsupported nucleoside was only achieved when reaching the temperature of $35-40{ }^{\circ} \mathrm{C}$. As acetonitrile could solubilize the PEG moiety at $0{ }^{\circ} \mathrm{C}$, it was also considered an alternative solvent. Thus, several experimental conditions (solvent, temperature, reaction times, and phosphorus oxychloride equivalents) were screened and selected data are presented in Table 1. Monophosphorylation conversion ratios were estimated with ${ }^{1} \mathrm{H}$ NMR analysis by comparing integration of the signals of the $\mathrm{H}_{6}$ or $\mathrm{H}_{5}$ nucleobase protons (Figure 3). Indeed, the signals of the $\mathrm{H}_{6}$ proton from the nucleoside $5^{\prime}$-monophosphate differed from that of the nucleoside by $60 \mathrm{~Hz}(0.2 \mathrm{ppm}$, downfield).

(52) Yoshikawa, M.; Kato, T. Bull. Chem. Soc. Jpn. 1967, 40, 2849-2853. 5068

(53) Yoshikawa, M.; Kato, T.; Takenish, T Tetrahedron Lett. 1967, 5065 -
These conversion ratios were also confirmed with HPLC analysis of a sample aliquot after cleavage of the succinyl linker in between the support and the nucleot(s)ide. In each case, regioselectivity of the phosphorylation (at the $5^{\prime}$-position) was evidenced by the ${ }^{1} \mathrm{H}$ NMR and ${ }^{31} \mathrm{P}$ NMR spectra. Longer reaction times did not improve the phosphorylation rate significantly (entries 5-7) whereas increasing the phosphorus oxychloride amount led to the reaction completion (entries 2-4 and 5, 8, and 11). Thus, the use of dry triethylphosphate appeared a better alternative than acetonitrile (entries 1 and 10). As both solvents were able to dissolve the substrate (PEG-araC) and the reactant $\left(\mathrm{POCl}_{3}\right)$, the effect of the triethylphosphate was attributed to the formation of a complex ${ }^{54}$ between the nucleobase and the 5'-hydroxyl function of the nucleoside, and not to solubility or temperature effects (as previously reported for solution phase synthesis). ${ }^{52,53}$ Finally, PEG-araCMP 3a was obtained by treating PEG-araC 2a with 15 equiv of $\mathrm{POCl}_{3}$ in $\mathrm{PO}(\mathrm{OEt})_{3}$ at $35-40{ }^{\circ} \mathrm{C}$ during $1 \mathrm{~h}$. After hydrolysis of the reaction mixture with TEAB (1M, $\mathrm{pH} 7.5)$, remaining salts were eliminated by a simple and easy extraction process (dichloromethane-water) and PEG-supported nucleoside $5^{\prime}$-monophosphate 3a was isolated in $92 \%$ yield, after precipitation in cold diethyl ether.

Recovery of araCMP (HPLC purity: 97\%) was performed after cleavage of the succinyl linker, using concentrated ammonia. A filtration of the crude through a reverse phase $\mathrm{RP}_{18}$ column was performed to eliminate PEG residue and succinimide (the byproduct generated from the cleavage of succinate linker) was removed by dialysis.

A similar procedure was applied to PEG-C $2 \mathbf{c}$ and the use of 30 equiv of $\mathrm{POCl}_{3}$ was required to observe the complete disappearance of the supported nucleoside. During the PEGdCMP 3b synthesis, the $3^{\prime}$-hydroxyl function also underwent phosphorylation at high temperature $\left(30-40{ }^{\circ} \mathrm{C}\right)$ and a mixture of both nucleoside $5^{\prime}$ - and $3^{\prime}$ - monophosphates was obtained. To avoid this lack of regioselectivity the reaction was performed in acetonitrile at $0{ }^{\circ} \mathrm{C}$. At lower temperature, only the desired nucleoside $5^{\prime}$-monophosphate 3b was observed and the use of 30 equiv of $\mathrm{POCl}_{3}$ was necessary to complete the reaction. Finally, CMP and dCMP were obtained after ammonia treatment; corresponding yields and purities are presented in Scheme 1.

(54) Ikemoto, T.; Haze, A.; Hatano, H.; Kitamoto, Y.; Ishida, M.; Nara, K. Chem. Pharm. Bull. 1995, 43, 210-215. 

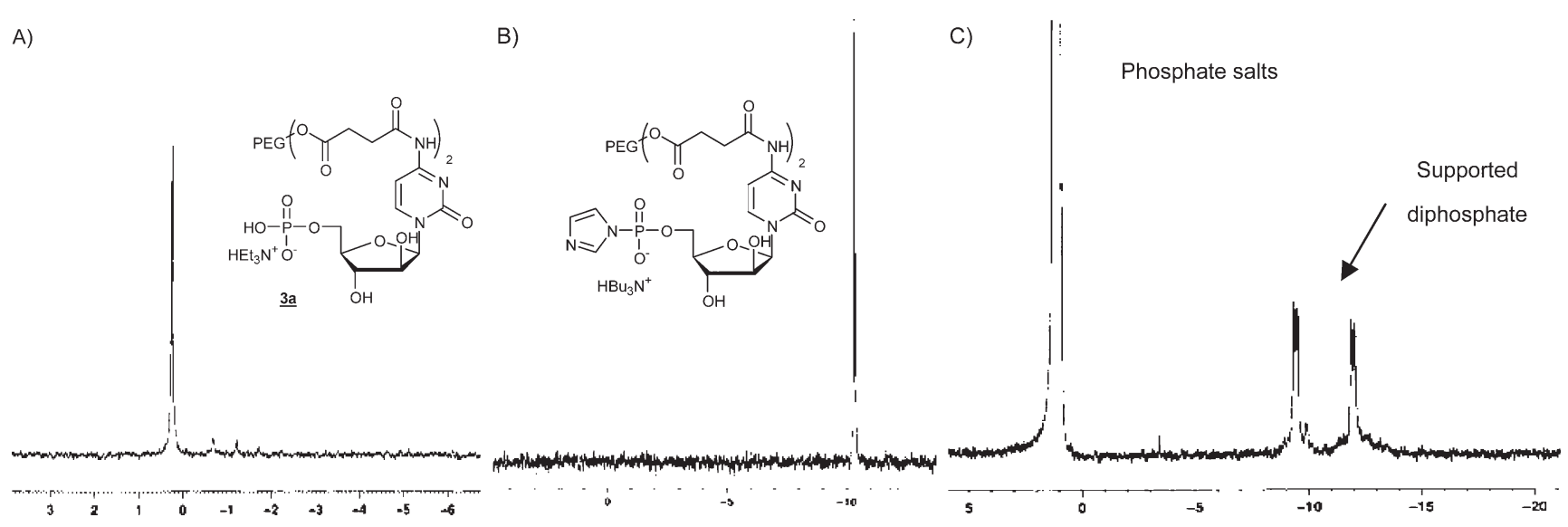

FIGURE 4. ${ }^{31} \mathrm{P}$ NMR (DMSO- $d_{6}$ ) spectra of the PEG-araCMP diphosphorylation procedure: (A) starting material PEG-araCMP; (B) reaction mixture, $3 \mathrm{~h}$ after $\mathrm{CDI}$ addition; and (C) reaction mixture $24 \mathrm{~h}$ after tri- $n$-butylammonium phosphate addition.

\section{SCHEME $2^{a}$}
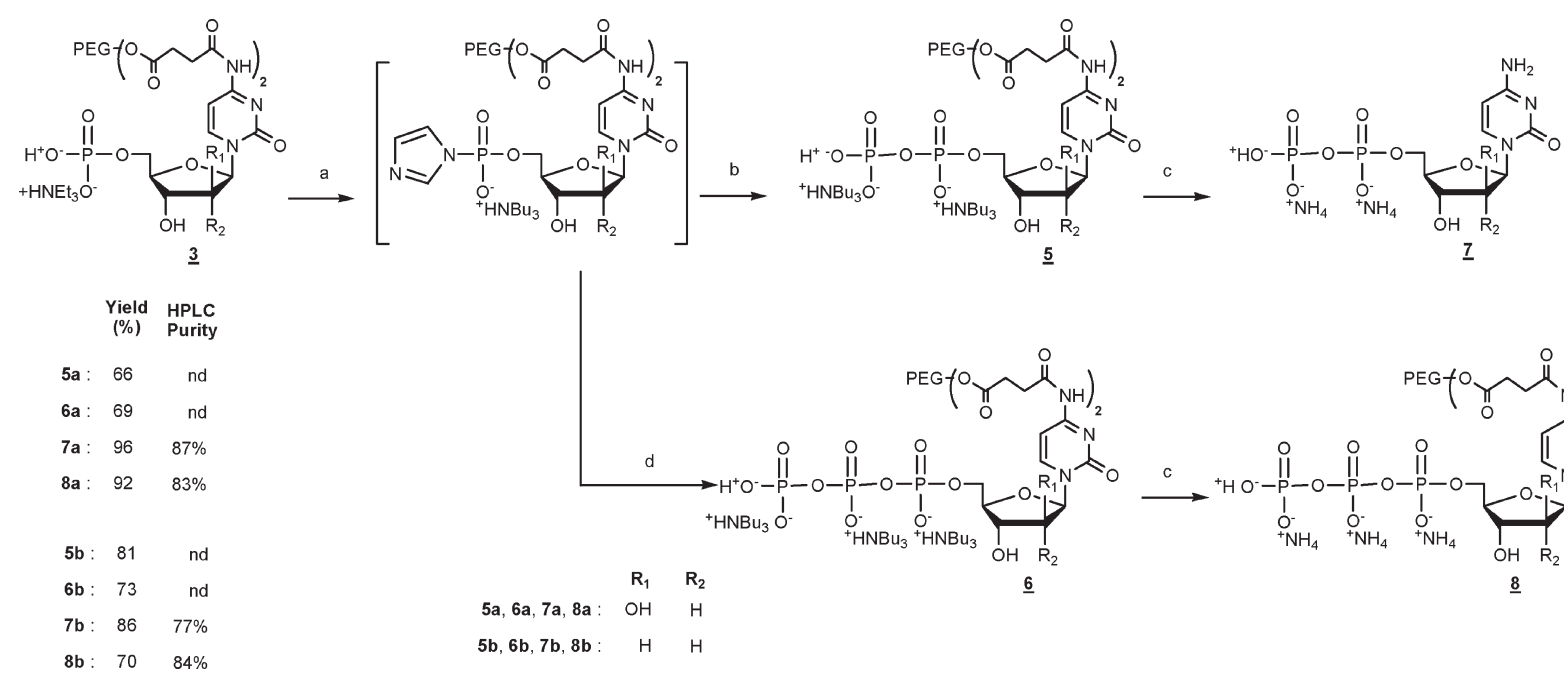

$\underline{6}$

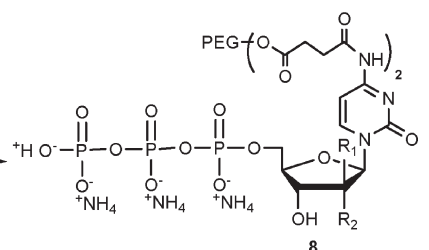

${ }^{a}$ Reagents and conditions: (a) CDI, DMF, rt, 3 h; (b) tri- $n$-butylammonium phosphate (1 M solution in DMF), rt, 24 h; (c) NH ${ }_{4} \mathrm{OH}_{\mathrm{c}}$, rt, 1 h; (d) tri- $n$ butylammonium pyrophosphate (1 M solution in DMF), rt, $24 \mathrm{~h}$.

Di- and Triphosphorylation Steps. The triphosphorylation procedure was first considered following the Ludwig et al. ${ }^{55}$ one-pot method, using unprotected nucleoside as starting material. Consequently, the phosphorodichloridate intermediate was generated with use of the monophosphorylation conditions previously optimized $\left(\mathrm{PO}(\mathrm{OEt})_{3}, 35-40{ }^{\circ} \mathrm{C}\right.$, 15 equiv of $\mathrm{POCl}_{3}, 1 \mathrm{~h}$ ) and the reaction mixture was treated by an excess of tri- $n$-butylammonium pyrophosphate (1 M solution in DMF). Unfortunately, hydrolysis and purification afforded a mixture of the mono- and the triphosphate-supported nucleosides with a prevalent proportion of PEG-araCMP 3a. As the completion of the reaction was a key factor for success, another method described by Hoard et al., ${ }^{56}$ which could easily be monitored by ${ }^{31} \mathrm{P}$ NMR analysis, was investigated. This procedure required the nucleoside $5^{\prime}$-monophosphate activation by 1,1-carbonyldiimidazole (CDI) and then condensation of

(55) Ludwig, J. Acta Biochim. Biophys. Acad. Sci. Hung. 1981, 16, 131133.

(56) Hoard, D. E.; Ott, D. G. J. Am. Chem. Soc. 1965, 87, 1785-1788. the $5^{\prime}$-phosphoroimidazolidate intermediate with inorganic phosphate or pyrophosphate, which led to the desired nucleoside 5'-di- or triphosphate derivatives (Scheme 2).

Formation of the imidazolidate from PEG-araCMP 3a in the presence of an excess of CDI (6 equiv) was complete after $3 \mathrm{~h}$. Indeed, the ${ }^{31} \mathrm{P}$ NMR signal corresponding to the supported nucleoside monophosphate (signal at $0 \mathrm{ppm}$, Figure 4A) disappeared whereas the concomitant formation of the imidazolidate (signal at $-10 \mathrm{ppm}$, Figure 4B) was observed. Unreacted $\mathrm{CDI}$ was decomposed with methanol and then a large excess of organic phosphate was added. As shown in Figure $4 \mathrm{C},{ }^{31} \mathrm{P}$ NMR signals observed after $24 \mathrm{~h}$ confirmed that activated imidazolidate species $(\delta-10 \mathrm{ppm})$ were efficiently converted to the diphosphate derivative (two peaks corresponding to $\mathrm{P}_{\beta}$ at $-9.2 \mathrm{ppm}$ and to $\mathrm{P}_{\alpha}$ at $-12 \mathrm{ppm}$ ). As the precipitation and extraction processes were not sufficient to eliminate the excess phosphate salts, purification of the PEG-supported nucleoside diphosphate 5a was performed by reverse phase C18 column chromatography. Elution with water removed all remaining salts and supported substrate was eluted with a mixture of water and acetonitrile $(50 / 50, \mathrm{v} / \mathrm{v})$. 
SCHEME $3^{a}$
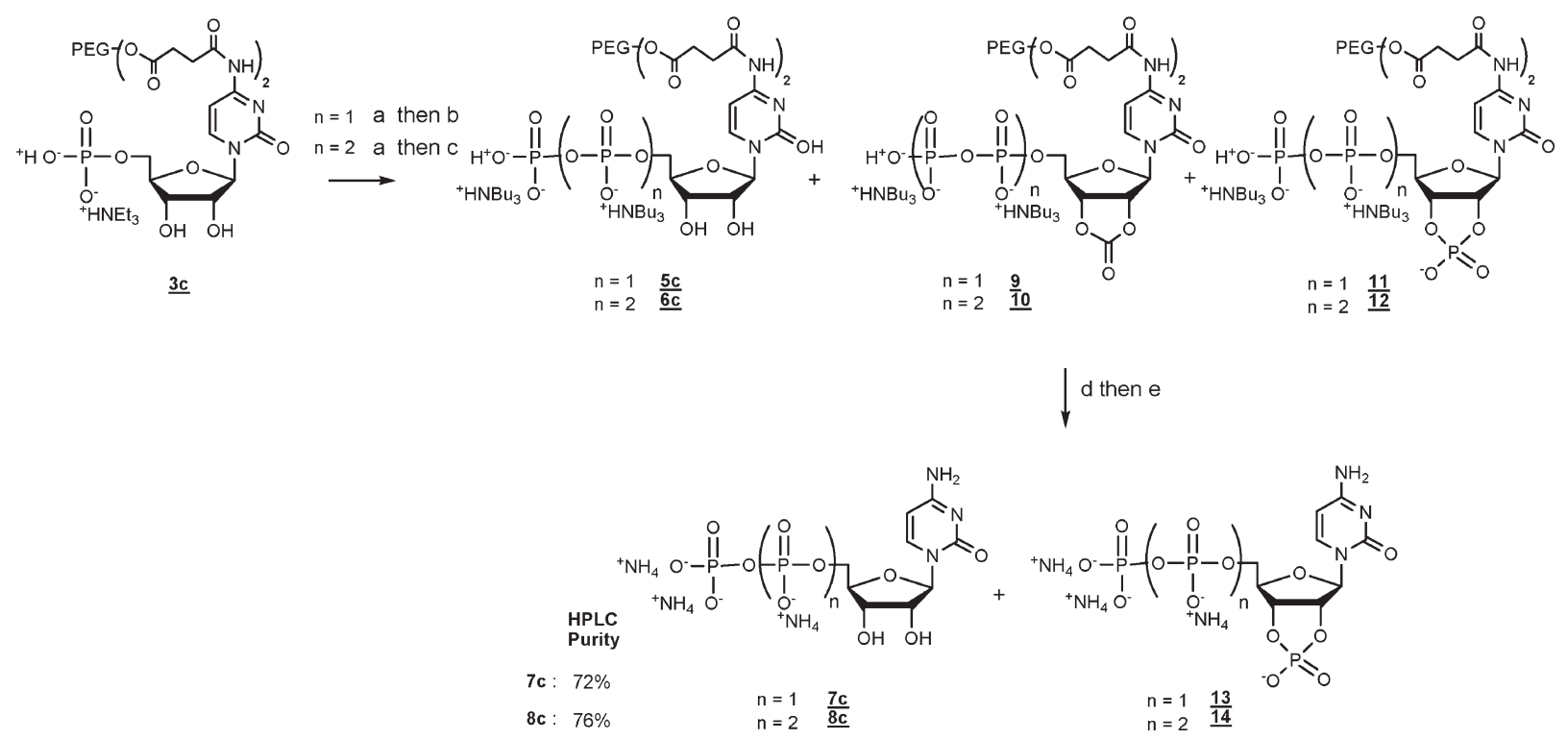

${ }^{a}$ Reagents and conditions: (a) CDI, DMF, rt, 3 h; (b) tri- $n$-butylammonium phosphate (1 M solution in DMF), rt, 24 h; (c) tri- $n$-butylammonium pyrophosphate (1 M solution in DMF), rt, 24 h; (d) EtOH- $\mathrm{H}_{2} \mathrm{O}, \mathrm{NEt}_{3}, \mathrm{rt}, 3 \mathrm{~h}$; (e) $\mathrm{NH}_{4} \mathrm{OH}_{\mathrm{c}}, \mathrm{rt}, 1 \mathrm{~h}$.

TABLE 2. Comparison of Solution and Supported Synthesis of Phosphoester Derivatives of araC

\begin{tabular}{|c|c|c|c|c|c|c|}
\hline & & solution & & & support & \\
\hline & yield $(\%)$ & HPLC purity (\%) & no. of steps & yield $^{a}(\%)$ & HPLC purity $(\%)$ & no. of steps \\
\hline $\operatorname{araCMP}, \mathbf{4 a}$ & $40-70$ & 98 & 1 & 60 & 97 & 3 \\
\hline $\operatorname{araCDP}, 7 \mathbf{a}$ & 45 & 84 & 2 & 53 & 87 & 4 \\
\hline $\operatorname{araCTP}, \mathbf{8 a}$ & 10 & 85 & 2 & 55 & 83 & 4 \\
\hline
\end{tabular}

${ }^{a}$ Overall yield for supported synthesis included coupling, phosphorylation, and cleavage and isolation steps.

The crude supported product was lyophilized to afford PEG-araCDP 5a in $66 \%$ yield. A similar procedure was applied for PEG-araCTP 6a synthesis (69\%), using tri- $n$ butylammonium pyrophosphate salts instead of tri- $n$-butylammonium phosphate salts. Then, treatment of $\mathbf{5 a}$ and $\mathbf{6 a}$ with concentrated aqueous ammonia yielded araCDP $7 \mathbf{a}$ and araCTP 8a, as ammonium salts, respectively, with $87 \%$ and $83 \%$ HPLC purity after RP18 purification and dialysis. Starting from PEG-dCMP $\mathbf{4 b}$, the same procedures were carried out and afforded either the dCDP $7 \mathbf{b}$ or the dCTP $\mathbf{8 b}$ (Scheme 2).

When applied to PEG-CMP 3c, these protocols led to the expected derivatives PEG-CDP 5c and PEG-CTP 6c as well as two side products (Scheme 3 ). The major contaminant was identified as the corresponding $2^{\prime}, 3^{\prime}$-protected nucleotide (9 or 10). Formation of these derivatives is due to the particular reactivity of the cis-diol functionality of ribosecontaining nucleosides in the presence of CDI excess. However, formation of these derivatives was not puzzling as concomitant removal of the $2^{\prime}, 3^{\prime}$-carbonate group was expected during the final cleavage step with basic conditions.

Structures of minor contaminants $\mathbf{1 1}$ and $\mathbf{1 2}$ (dioxaphospholane derivatives involving a cyclic monophosphate between the $2^{\prime}$ and the $3^{\prime}$ positions) were proposed on the basis of the presence of an extra phosphate signal at $\delta 19 \mathrm{ppm}$, already described in the literature for $2^{\prime}, 3^{\prime}$-cyclic phosphate nucleosides. ${ }^{57,58}$ Furthermore, the HPLC-MS analysis of the

(57) Davies, D. B.; Sadikot, H. J. Chem. Soc., Perkin Trans. 2 1983, 1251-1258. (58) El-Tayeb, A.; Qi, A. D.; Muller, C. E. J. Med.Chem. 2006, 49, 7076-7087. crude mixture after cleavage showed peaks corresponding to compounds 13 and 14. In the meantime, El Tayeb et al. ${ }^{58}$ reported that phosphorylation of the $2^{\prime}$ - and $3^{\prime}$-hydroxy groups may occurred during the triphosphorylation, ${ }^{55}$ and this side reaction is associated with the presence of bulky substituents on the pyrimidine nucleobase. In our case, steric hindrance of PEG support attached onto the nucleobase may be involved in the $2^{\prime}, 3^{\prime}$ phosphorylation process. Indeed, such a side reaction was not observed when the reaction was performed in solution from unprotected cytidine $5^{\prime}$-monophosphate (cf. CTP solution synthesis).

Thus, after performing the cleavage step CDP 7c or CTP 8c was obtained, albeit contaminated by a small amount of $2^{\prime}, 3^{\prime}$-cyclic phosphate 13 or $\mathbf{1 4}$ (7\% and $10 \%$, respectively) and unfortunately final purification on reverse phase did not allow the separation of this byproduct.

Comparison between Solution and Supported Nucleotide Synthesis. To compare our novel soluble PEG-supported methodology to the corresponding synthesis in solution (in terms of number of step, yields, and HPLC purities, Table 2) we also prepared araCMP, araCDP, and araCTP using traditional methods.

AraCMP was obtained by solution phase synthesis, using phosphorus oxychloride in $\mathrm{PO}(\mathrm{OEt})_{3}$ as previously reported by Yoshikawa. ${ }^{52,53}$ After cumbersome purification steps (ion exchange chromatography DEAE-Sephadex, reverse phase C18 chromatography, and conversion into sodium salt with Dowex resin) araCMP was recovered in modest to good yields depending of the reaction scale $(70 \%$ for $200 \mathrm{mg}$ of 
starting material and $40 \%$ for $1 \mathrm{~g}$ ). This result is mainly due to the numerous purification steps needed to eliminate the remaining salt on a larger scale. Supported monophosphorylation was also carried out on two different scales (200 mg and $1 \mathrm{~g}$ of supported nucleoside), meanwhile no variation on the overall yields was observed $(60 \%$ including coupling of the nucleoside to the support, monophosphorylation, and cleavage steps). Solution synthesis of araCDP and araCTP was also performed following the Hoard et al. ${ }^{56}$ method starting from araCMP. For the araCDP synthesis yields on both support and in solution were similar $(\sim 50 \%)$. Remarkably, using our supported methodology the yield of the nucleoside 5'-triphosphate synthesis was 5-fold the one obtained by the solution approach.

One can see that we also succeeded in reaching similar HLPC purities with 5'-mono-, di-, and triphosphate nucleoside-supported synthesis (Table 2), without performing ion-exchange DEAE-Sephadex purification but only using precipitation/ extraction or precipitation/RP18 filtration processes.

\section{Conclusion}

We have set up a new synthetic approach for the supported synthesis of nucleoside phosphoesters using PEG as a soluble support. Compared to classical solution procedures, our methodology is efficient, scalable, and easy to handle. Thus, cytosine-containing nucleoside $5^{\prime}$-mono, di-, and triphosphate derivatives were prepared in similar higher yields with acceptable purity. Furthermore, the isolation procedures have been simplified and led to a reduction in the overall process time.

\section{Experimental Section}

General Procedure for PEG-Supported Nucleoside Synthesis. To a stirred solution of PEG succinate $\mathbf{1}$ ( $0.95 \mathrm{mmol}, 1$ equiv) in dichloromethane $(70 \mathrm{~mL})$ was added a solution of the required nucleoside (2 equiv) in DMF (30 mL). Then, DCC (3.79 mmol, 4 equiv) and HOBT (1.89 mmol, 2 equiv) were added and the resulting mixture was stirred at $60{ }^{\circ} \mathrm{C}$ for $7 \mathrm{~h}$. The solvents were evaporated under reduced pressure; the residue was dissolved in a minimum of dichloromethane and left overnight at $4{ }^{\circ} \mathrm{C}$. The dicyclohexyl urea was filtered off, and the filtrate was concentrated under reduced pressure and dissolved in DMF $(40 \mathrm{~mL})$. The resulting solution was slowly added to an excess volume of cold diethyl ether $(400 \mathrm{~mL})$. The precipitate was filtered and washed with diethyl ether. The final product was recrystallized from absolute ethanol $(40 \mathrm{~mL})$ and dried under vacuum over $\mathrm{KOH}$ pellets.

Poly(ethylene glycol $)_{4000}$ bis[4- $N-(1-(\beta$-D-arabinofuranosyl)cytosyl)succinate] 2a: Coupling between PEG succinate 1 (4 g, $0.95 \mathrm{mmol})$ and araC $(0.46 \mathrm{~g}, 1.89 \mathrm{mmol})$ was performed with the general procedure and afforded compound $\mathbf{2 a}$ as a white solid (3.65 g, 83\%). $R_{f}\left(\mathrm{CH}_{2} \mathrm{Cl}_{2} / \mathrm{MeOH}, 7 / 3, \mathrm{v} / \mathrm{v}\right) 0.7 ; \delta_{\mathrm{H}}$ $\left(200 \mathrm{MHz} ; \mathrm{D}_{2} \mathrm{O}\right) 8.16\left(\mathrm{~d}, J_{6-5}=7.5 \mathrm{~Hz}, 1 \mathrm{H}, \mathrm{H}_{6}\right), 7.26\left(\mathrm{~d}, J_{5-6}=\right.$ $\left.7.5 \mathrm{~Hz}, 1 \mathrm{H}, \mathrm{H}_{5}\right), 6.10\left(\mathrm{~d}, J_{1^{\prime}-2^{\prime}}=4.6 \mathrm{~Hz}, 1 \mathrm{H}, \mathrm{H}_{1^{\prime}}\right), 4.34(\mathrm{pt}, J=$ $\left.4.6 \mathrm{~Hz}, 1 \mathrm{H}, \mathrm{H}_{2^{\prime}}\right), 4.16\left(\mathrm{~m}, 2 \mathrm{H},\left(\mathrm{OCH}_{2} \alpha\right)_{\mathrm{PEG}}\right), 4.02-3.92(\mathrm{~m}, 2 \mathrm{H}$, $\left.\mathrm{H}_{3^{\prime}} \mathrm{H}_{4^{\prime}}\right), 3.73\left(\mathrm{~m}, 2 \mathrm{H}, \mathrm{H}_{5^{\prime} \mathrm{a}} \mathrm{H}_{5^{\prime} \mathrm{b}}\right), 3.70-3.33\left(\mathrm{~m},\left(\mathrm{OCH}_{2}\right)_{\mathrm{PEG}}\right)$, $2.76-2.62\left(\mathrm{~m}, 4 \mathrm{H}, \mathrm{CH}_{2 \text { succ }}\right) ; \delta_{\mathrm{C}}\left(75 \mathrm{MHz} ; \mathrm{D}_{2} \mathrm{O}\right) 174.6,174.5(2 \mathrm{~s}$, $\left.\mathrm{C}=\mathrm{O}_{\text {succ }}\right), 162.5\left(\mathrm{~s}, \mathrm{C}_{4}\right), 156.7\left(\mathrm{~s}, \mathrm{C}_{2}\right), 146.7\left(\mathrm{~s}, \mathrm{C}_{6}\right), 97.3\left(\mathrm{~s}, \mathrm{C}_{5}\right)$, $87.1\left(\mathrm{~s}, \mathrm{C}_{1^{\prime}}\right), 84.0\left(\mathrm{~s}, \mathrm{C}_{4^{\prime}}\right), 75.4\left(\mathrm{~s}, \mathrm{C}_{2^{\prime}}\right), 75.2\left(\mathrm{~s}, \mathrm{C}_{3^{\prime}}\right), 69.6(\mathrm{~s}$, $\left.\left(\mathrm{OCH}_{2}\right)_{\mathrm{PEG}}\right), 68.4\left(\mathrm{~s},\left(\mathrm{OCH}_{2} \beta\right)_{\mathrm{PEG}}\right), 64.1\left(\mathrm{~s},\left(\mathrm{OCH}_{2} \alpha\right)_{\mathrm{PEG}}\right), 60.7$ $\left(\mathrm{s}, \mathrm{C}_{5^{\prime}}\right), 31.5,28.5\left(2 \mathrm{~s}, \mathrm{CH}_{2 \text { succ }}\right)$.

General Procedure for the Monophosphorylation of PolymerSupported Nucleoside. A solution of PEG-supported nucleoside (1 equiv) in triethylphosphate $(10 \mathrm{~mL} / \mathrm{mmol})$ was warmed to $40{ }^{\circ} \mathrm{C}$. Phosphorus oxychloride ( 15 equiv) was added and the mixture was stirred for $1 \mathrm{~h}$ at $40{ }^{\circ} \mathrm{C}$. Excess of reagent was hydrolyzed by addition of an aqueous triethylammonium bicarbonate buffer solution ( $1 \mathrm{M}, \mathrm{pH} 7)$ and the resulting mixture was concentrated under reduced pressure. The residue was dissolved in dichloromethane and the organic layer was washed with water. The aqueous layer was extracted several times by dichloromethane. The organic layers were combined and evaporated under reduced pressure. The supported nucleoside 5'-monophosphate was precipitated from a dichloromethane solution by addition of an excess volume of cold diethyl ether. The precipitate was filtered, washed with diethyl ether, and dried under vacuum over $\mathrm{KOH}$.

Poly $(\text { ethylene glycol })_{4000}$ bis $\left[4-N-\left(1-\left(5^{\prime}-O\right.\right.\right.$-monophosphoryl- $\beta$ D-arabinofuranosyl)cytosyl)succinate], triethylammonium salt 3a: Monophosphorylation of PEG-araC 2a (3 g, $0.64 \mathrm{mmol})$ was performed with the general procedure and afforded compound 3a as a white solid $(2.99 \mathrm{~g}, 92 \%) . \delta_{\mathrm{H}}\left(300 \mathrm{MHz} ; \mathrm{D}_{2} \mathrm{O}\right) 8.34$ $\left(\mathrm{d}, J_{6-5}=7.5 \mathrm{~Hz}, 1 \mathrm{H}, \mathrm{H}_{6}\right), 7.10\left(\mathrm{~d}, J_{5-6}=7.5 \mathrm{~Hz}, 1 \mathrm{H}, \mathrm{H}_{5}\right), 6.18$ $\left(\mathrm{d}, J_{1^{\prime}-2^{\prime}}=5.0 \mathrm{~Hz}, 1 \mathrm{H}, \mathrm{H}_{1^{\prime}}\right), 4.42\left(\mathrm{~m}, 1 \mathrm{H}, \mathrm{H}_{2^{\prime}}\right), 4.19(\mathrm{~m}, 2 \mathrm{H}$, $\left.\left(\mathrm{OCH}_{2} \alpha\right)_{\mathrm{PEG}}\right), 4.10-4.15\left(\mathrm{~m}, 4 \mathrm{H}, \mathrm{H}_{3^{\prime}} \mathrm{H}_{4^{\prime}} \mathrm{H}_{5^{\prime} \mathrm{a}} \mathrm{H}_{5^{\prime} \mathrm{b}}\right), 3.30-3.90$ $\left(\mathrm{m},\left(\mathrm{OCH}_{2}\right)_{\mathrm{PEG}}\right), 3.10\left(\mathrm{q}, J=7.3 \mathrm{~Hz}, 6 \mathrm{H},\left(\mathrm{CH}_{3} \mathrm{CH}_{2}\right)_{3} \mathrm{NH}\right)$, $2.62-2.85\left(\mathrm{~m}, 4 \mathrm{H}, \mathrm{CH}_{2 \mathrm{succ}}\right), 1.18\left(\mathrm{t}, J=7.3 \mathrm{~Hz}, 9 \mathrm{H},\left(\mathrm{CH}_{3^{-}}\right.\right.$ $\left.\left.\mathrm{CH}_{2}\right)_{3} \mathrm{NH}\right) ; \delta_{\mathrm{C}}\left(100 \mathrm{MHz} ; \mathrm{D}_{2} \mathrm{O}\right) 174.7,174.4\left(2 \mathrm{~s}, \mathrm{C}=\mathrm{O}_{\text {succ }}\right)$, $159.0\left(\mathrm{~s}, \mathrm{C}_{4}\right), 148.1\left(\mathrm{~s}, \mathrm{C}_{2}\right), 145.2\left(\mathrm{~s}, \mathrm{C}_{6}\right), 96.9\left(\mathrm{~s}, \mathrm{C}_{5}\right), 87.0\left(\mathrm{~s}, \mathrm{C}_{1^{\prime}}\right)$, $82.3\left(\mathrm{~d}, J_{\mathrm{C}^{\prime}-\mathrm{P}}=8.0 \mathrm{~Hz}, \mathrm{C}_{4^{\prime}}\right), 75.8\left(\mathrm{~s}, \mathrm{C}_{2^{\prime}}\right), 74.1\left(\mathrm{~s}, \mathrm{C}_{3^{\prime}}\right), 69.6(\mathrm{~s}$, $\left.\left.\left(\mathrm{OCH}_{2}\right)_{\mathrm{PEG}}\right), 68.4\left(\mathrm{~s},\left(\mathrm{OCH}_{2} \beta\right)_{\mathrm{PEG}}\right), 64.1\left(\mathrm{~s}, \mathrm{OCH}_{2} \alpha\right)_{\mathrm{PEG}}\right), 63.6$ $\left(\mathrm{s}, \mathrm{C}_{5^{\prime}}\right), 46.6\left(\mathrm{~s},\left(\mathrm{CH}_{3} \mathrm{CH}_{2}\right)_{3} \mathrm{NH}\right), 31.6,28.3\left(2 \mathrm{~s}, \mathrm{CH}_{2 \text { succ }}\right), 8.2$ (s, $\left.\left(\mathrm{CH}_{3} \mathrm{CH}_{2}\right)_{3} \mathrm{NH}\right) ; \delta_{\mathrm{P}}\left(121 \mathrm{MHz} ; \mathrm{D}_{2} \mathrm{O}\right) 0.26$ (s).

General Procedure for the Diphosphorylation of PolymerSupported Nucleoside. A suspension of PEG-supported nucleoside $5^{\prime}$-monophosphate (1 equiv) in tributylamine $(10 \mathrm{mmol}$, 100 equiv) was stirred for $10 \mathrm{~min}$ at room temperature. Cold diethyl ether was added and the precipitate was filtered, washed with diethyl ether, and dried overnight under vacuum over $\mathrm{KOH}$ pellets. Then, the supported nucleoside $5^{\prime}$-monophosphate was dissolved in anhydrous DMF (10 mL/mmol) and CDI (6 equiv) was added. The reaction mixture was stirred for $2 \mathrm{~h}$ at room temperature and treated with anhydrous methanol ( 24 equiv) to hydrolyze the excess of CDI. After $15 \mathrm{~min}$, a solution of tributylammonium phosphate (1 $\mathrm{M}$ solution in anhydrous DMF, 15 equiv) was added and the suspension was stirred for $24 \mathrm{~h}$ at room temperature. The mixture was treated with an equal volume of methanol and then concentrated under reduced pressure. The residue was precipitated with cold diethyl ether; the precipitate was filtered and washed with diethyl ether. Purification of the crude material was performed on reverse phase column (linear gradient from water to $70 \%$ acetonitrile in water).

Poly(ethylene glycol $)_{4000}$ bis $\left[4-N-\left(1-\left(5^{\prime}-O\right.\right.\right.$-diphosphoryl- $\beta$-Darabinofuranosyl)cytosyl)succinate], tributylammonium salt 5a: Diphosphorylation of PEG-araCMP 3a (0.50 g, $0.09 \mathrm{mmol})$ was performed with the general procedure and afforded compound $5 \mathbf{a}$ as a white solid $(0.36 \mathrm{~g}, 66 \%)$ after freeze-drying. $\delta_{\mathrm{H}}$ $\left(300 \mathrm{MHz} ; \mathrm{D}_{2} \mathrm{O}\right) 8.24\left(\mathrm{~d}, J_{6-5}=7.5 \mathrm{~Hz}, 1 \mathrm{H}, \mathrm{H}_{6}\right), 7.27\left(\mathrm{~d}, J_{5-6}=\right.$ $\left.7.5 \mathrm{~Hz}, 1 \mathrm{H}, \mathrm{H}_{5}\right), 6.17\left(\mathrm{~d}, J_{1^{\prime}-2},=5.1 \mathrm{~Hz}, 1 \mathrm{H}, \mathrm{H}_{1^{\prime}}\right), 4.42(\mathrm{pt}, J=$ $\left.5.1 \mathrm{~Hz}, 1 \mathrm{H}, \mathrm{H}_{2^{\prime}}\right), 4.28-4.05\left(\mathrm{~m}, 6 \mathrm{H}, \mathrm{H}_{3^{\prime}} \mathrm{H}_{4^{\prime}} \mathrm{H}_{5^{\prime} \mathrm{a}} \mathrm{H}_{5^{\prime} \mathrm{b}}\right.$ $\left.\left(\mathrm{OCH}_{2} \alpha\right)_{\mathrm{PEG}}\right), 3.89-3.35\left(\mathrm{~m},\left(\mathrm{OCH}_{2}\right)_{\mathrm{PEG}}\right), 2.92(\mathrm{t}, J=$ $\left.7.7 \mathrm{~Hz}, 12 \mathrm{H},\left(\mathrm{CH}_{3} \mathrm{CH}_{2} \mathrm{CH}_{2} \mathrm{CH}_{2}\right)_{3} \mathrm{NH}\right), 2.80-2.68(\mathrm{~m}, 4 \mathrm{H}$, $\left.\mathrm{CH}_{2 \text { succ }}\right), \quad 1.54$ (m, 12H, $\left.\left(\mathrm{CH}_{3} \mathrm{CH}_{2} \mathrm{CH}_{2} \mathrm{CH}_{2}\right)_{3} \mathrm{NH}\right), 1.29$ $\left(\mathrm{m}, 12 \mathrm{H},\left(\mathrm{CH}_{3} \mathrm{CH}_{2} \mathrm{CH}_{2} \mathrm{CH}_{2}\right)_{3} \mathrm{NH}\right), 0.81(\mathrm{t}, \mathrm{J}=7.2 \mathrm{~Hz}, 18 \mathrm{H}$, $\left.\left(\mathrm{CH}_{3} \mathrm{CH}_{2} \mathrm{CH}_{2} \mathrm{CH}_{2}\right)_{3} \mathrm{NH}\right) ; \delta_{\mathrm{C}}\left(100 \mathrm{MHz} ; \mathrm{D}_{2} \mathrm{O}\right) 174.6,174.4(2 \mathrm{~s}$, $\left.\mathrm{C}=\mathrm{O}_{\text {succ }}\right), 162.5\left(\mathrm{~s}, \mathrm{C}_{4}\right), 156.8\left(\mathrm{~s}, \mathrm{C}_{2}\right), 146.8\left(\mathrm{~s}, \mathrm{C}_{6}\right), 97.6\left(\mathrm{~s}, \mathrm{C}_{5}\right), 86.6$ $\left(\mathrm{s}, \mathrm{C}_{1^{\prime}}\right), 82.0\left(\mathrm{~d}, J_{\mathrm{C}^{\prime}-\mathrm{P}}=9.0 \mathrm{~Hz}, \mathrm{C}_{4^{\prime}}\right), 75.1\left(\mathrm{~s}, \mathrm{C}_{2^{\prime}}\right), 74.3\left(\mathrm{~s}, \mathrm{C}_{3^{\prime}}\right), 69.6$ $\left(\mathrm{s},\left(\mathrm{OCH}_{2}\right)_{\mathrm{PEG}}\right), 68.4\left(\mathrm{~s},\left(\mathrm{OCH}_{2} \beta\right)_{\mathrm{PEG}}\right), 64.1\left(\mathrm{~s},\left(\mathrm{OCH}_{2} \alpha\right)_{\mathrm{PEG}}\right), 64.1$ $\left(\mathrm{s}, \mathrm{C}_{5^{\prime}}\right), 52.6\left(\mathrm{~s},\left(\mathrm{CH}_{3} \mathrm{CH}_{2} \mathrm{CH}_{2} \mathrm{CH}_{2}\right)_{3} \mathrm{NH}\right), 31.6,28.4\left(2 \mathrm{~s}, \mathrm{CH}_{2 \text { succ }}\right)$, $25.2\left(\mathrm{~s},\left(\mathrm{CH}_{3} \mathrm{CH}_{2} \mathrm{CH}_{2} \mathrm{CH}_{2}\right)_{3} \mathrm{NH}\right), 19.2\left(\mathrm{~s}, \mathrm{CH}_{3} \mathrm{CH}_{2} \mathrm{CH}_{2} \mathrm{CH}_{2}\right)_{3} \mathrm{NH}-$ ), $12.8\left(\mathrm{~s},\left(\mathrm{CH}_{3} \mathrm{CH}_{2} \mathrm{CH}_{2} \mathrm{CH}_{2}\right)_{3} \mathrm{NH}\right) ; \delta_{\mathrm{P}}\left(121 \mathrm{MHz}, \mathrm{D}_{2} \mathrm{O}\right)-10.44$ $\left(\mathrm{m}, \mathrm{P}_{\beta}\right),-11.03\left(\mathrm{~m}, \mathrm{P}_{\alpha}\right)$. 
General Procedure for the Triphosphorylation of PolymerSupported Nucleoside 5'-Monophosphate. A suspension of PEG-supported nucleoside $5^{\prime}$-monophosphate (1 equiv) in tributylamine (10 mmol, 100 equiv) was stirred for $10 \mathrm{~min}$ at room temperature. Then, cold diethyl ether was added and the precipitate was filtered, washed, and dried overnight under vacuum over $\mathrm{KOH}$ pellets. The resulting supported nucleoside $5^{\prime}$-monophosphate was dissolved in anhydrous DMF $(10 \mathrm{~mL} / \mathrm{mmol})$ and CDI (6 equiv) was added. The anhydrous reaction mixture was stirred for $2 \mathrm{~h}$ at room temperature and treated with anhydrous methanol (24 equiv) to hydrolyze the CDI excess. After $15 \mathrm{~min}$, a solution of tributylammonium pyrophosphate $(1 \mathrm{M}$ solution in anhydrous DMF, 15 equiv) was added. The suspension was stirred for $24 \mathrm{~h}$ at room temperature. The mixture was treated with an equal volume of methanol and then concentrated under reduced pressure. The residue was precipitated with cold diethyl ether. The precipitate was filtered and washed with diethyl ether. Column chromatography of the crude material was performed on reverse phase (linear gradient from water to $70 \%$ acetonitrile in water).

Poly(ethylene glycol $)_{4000}$ bis $\left[4-N-\left(1-\left(5^{\prime}-O\right.\right.\right.$-triphosphoryl- $\beta$-Darabinofuranosyl)cytosyl)succinate], tributylammonium salt $6 \mathrm{a}$ : Triphosphorylation of PEG-araCMP 3a $(0.50 \mathrm{~g}, 0.09 \mathrm{mmol})$ was performed with the general procedure and afforded compound $\mathbf{6 a}$ as a white solid $(0.43 \mathrm{~g}, 69 \%)$ after freeze-drying. $\delta_{\mathrm{H}}\left(300 \mathrm{MHz} ; \mathrm{D}_{2} \mathrm{O}\right) 8.29\left(\mathrm{~d}, J_{6-5}=7.5 \mathrm{~Hz}, 1 \mathrm{H}, \mathrm{H}_{6}\right), 7.17(\mathrm{~d}$, $\left.J_{5-6}=7.5 \mathrm{~Hz}, 1 \mathrm{H}, \mathrm{H}_{5}\right), 6.17\left(\mathrm{~d}, J_{1^{\prime}-2},=5.1 \mathrm{~Hz}, 1 \mathrm{H}, \mathrm{H}_{1^{\prime}}\right), 4.41$ (pt, $\left.J=5.1 \mathrm{~Hz}, 1 \mathrm{H}, \mathrm{H}_{2^{\prime}}\right), 4.27-4.05\left(\mathrm{~m}, 6 \mathrm{H}, \mathrm{H}_{3^{\prime}} \mathrm{H}_{4^{\prime}} \mathrm{H}_{5^{\prime} \mathrm{a}} \mathrm{H}_{5^{\prime} \mathrm{b}}\right.$ $\left.\left(\mathrm{OCH}_{2} \alpha\right)_{\mathrm{PEG}}\right), 3.88-3.30\left(\mathrm{~m},\left(\mathrm{OCH}_{2}\right)_{\mathrm{PEG}}\right), 3.03(\mathrm{t}, J=7.4 \mathrm{~Hz}$, $\left.18 \mathrm{H},\left(\mathrm{CH}_{3} \mathrm{CH}_{2} \mathrm{CH}_{2} \mathrm{CH}_{2}\right)_{3} \mathrm{NH}\right), 2.87-2.65\left(\mathrm{~m}, 4 \mathrm{H}, \mathrm{CH}_{2 \text { succ }}\right.$ ), $1.57\left(\mathrm{~m}, 18 \mathrm{H},\left(\mathrm{CH}_{3} \mathrm{CH}_{2} \mathrm{CH}_{2} \mathrm{CH}_{2}\right)_{3} \mathrm{NH}\right), 1.27\left(\mathrm{~m}, 18 \mathrm{H},\left(\mathrm{CH}_{3^{-}}\right.\right.$ $\left.\left.\mathrm{CH}_{2} \mathrm{CH}_{2} \mathrm{CH}_{2}\right)_{3} \mathrm{NH}\right), 0.83\left(\mathrm{t}, \mathrm{J}=7.1 \mathrm{~Hz}, 27 \mathrm{H},\left(\mathrm{CH}_{3} \mathrm{CH}_{2} \mathrm{CH}_{2^{-}}\right.\right.$ $\left.\left.\mathrm{CH}_{2}\right)_{3} \mathrm{NH}\right) ; \delta_{\mathrm{C}}\left(100 \mathrm{MHz} ; \mathrm{D}_{2} \mathrm{O}\right) 174.7,174.5\left(2 \mathrm{~s}, \mathrm{C}=\mathrm{O}_{\text {succ }}\right)$, $161.5\left(\mathrm{~s}, \mathrm{C}_{4}\right), 155.1\left(\mathrm{~s}, \mathrm{C}_{2}\right), 147.6\left(\mathrm{~s}, \mathrm{C}_{6}\right), 97.2\left(\mathrm{~s}, \mathrm{C}_{5}\right), 86.6\left(\mathrm{~s}_{1} \mathrm{C}_{1^{\prime}}\right)$, $82.0\left(\mathrm{~d}, J_{\mathrm{C}^{\prime}-\mathrm{P}}=9.0 \mathrm{~Hz}, \mathrm{C}_{4^{\prime}}\right), 75.2\left(\mathrm{~s}, \mathrm{C}_{2^{\prime}}\right), 74.0\left(\mathrm{~s}, \mathrm{C}_{3^{\prime}}\right), 69.6(\mathrm{~s}$, $\left.\left(\mathrm{OCH}_{2}\right)_{\mathrm{PEG}}\right), 68.4\left(\mathrm{~s},\left(\mathrm{OCH}_{2} \beta\right)_{\mathrm{PEG}}\right), 64.2\left(\mathrm{~s},\left(\mathrm{OCH}_{2} \alpha\right)_{\mathrm{PEG}}\right), 64.1$ $\left(\mathrm{d}, J_{\mathrm{C}^{\prime}-\mathrm{P}}=8.0 \mathrm{~Hz}, \mathrm{C}_{5^{\prime}}\right), 52.6\left(\mathrm{~s},\left(\mathrm{CH}_{3} \mathrm{CH}_{2} \mathrm{CH}_{2} \mathrm{CH}_{2}\right)_{3} \mathrm{NH}\right)$, 31.6, 28.4 (2s, $\mathrm{CH}_{2 \text { succ }}$ ), 25.2 (s, $\left.\left(\mathrm{CH}_{3} \mathrm{CH}_{2} \mathrm{CH}_{2} \mathrm{CH}_{2}\right)_{3} \mathrm{NH}\right)$, $\left.18.3\left(\mathrm{~s}, \quad \mathrm{CH}_{3} \mathrm{CH}_{2} \mathrm{CH}_{2} \mathrm{CH}_{2}\right)_{3} \mathrm{NH}\right), 12.8\left(\mathrm{~s}, \quad\left(\mathrm{CH}_{3} \mathrm{CH}_{2} \mathrm{CH}_{2^{-}}\right.\right.$ $\left.\left.\mathrm{CH}_{2}\right)_{3} \mathrm{NH}\right) ; \delta_{\mathrm{P}}\left(121 \mathrm{MHz}, \mathrm{D}_{2} \mathrm{O}\right)-10.94\left(\mathrm{~d}, J_{\gamma-\beta}=19.4 \mathrm{~Hz}\right.$, $\left.\mathrm{P}_{\gamma}\right),-11.32\left(\mathrm{~d}, J_{\alpha-\beta}=19.4 \mathrm{~Hz}, \mathrm{P}_{\alpha}\right),-23.28\left(\mathrm{t}, J_{\beta-\gamma}=J_{\beta-\alpha}=\right.$ 19.4 Hz, $\mathrm{P}_{\beta}$ ).

General Procedure for the Cleavage of Supported Substrates and Nucleotides Recovery. PEG-supported nucleotide (0.05 mmol, 1 equiv) was dissolved in concentrated ammonia $(2 \mathrm{~mL})$. The solution was stirred at room temperature for $1 \mathrm{~h}$ and then evaporated under reduced pressure. Purification was performed on reverse phase column (elution with water) and dialysis.

1-( $\beta$-D-Arabinofuranosyl)cytosine-5'-monophosphate, ammonium salt 4a: The general procedure was applied to PEG-araCMP 3a $(0.15 \mathrm{~g}, 0.02 \mathrm{mmol})$ and led to a mixture $(15 \mathrm{mg})$ of araCMP and succinamide (ratio: 93/7). The succinamide was eliminated by dialysis in water $(2 \mathrm{~mL})$ overnight and araCMP $4 \mathbf{a}$
(13 mg, 68\%) was recovered as a white solid after freeze-drying. $\lambda_{\max }\left(\mathrm{H}_{2} \mathrm{O}\right) / 272 \mathrm{~nm}\left(\varepsilon / \mathrm{dm}^{3} \mathrm{~mol}^{-1} \mathrm{~cm}^{-1} 7100\right), 247$ (4100); $\delta_{\mathrm{H}}\left(300 \mathrm{MHz} ; \mathrm{D}_{2} \mathrm{O}\right) 7.88\left(\mathrm{~d}, J_{6-5}=7.6 \mathrm{~Hz}, 1 \mathrm{H}, \mathrm{H}_{6}\right), 6.11(\mathrm{~d}$, $\left.J_{1^{\prime}-2^{\prime}}=5.3 \mathrm{~Hz}, 1 \mathrm{H}, \mathrm{H}_{1^{\prime}}\right), 6.02\left(\mathrm{~d}, J_{5-6}=7.6 \mathrm{~Hz}, 1 \mathrm{H}, \mathrm{H}_{5}\right), 4.34(\mathrm{pt}$, $\left.J=5.3 \mathrm{~Hz} 1 \mathrm{H}, \mathrm{H}_{2^{\prime}}\right), 4.11-3.96\left(\mathrm{~m}, 4 \mathrm{H}, \mathrm{H}_{3^{\prime}} \mathrm{H}_{4^{\prime}} \mathrm{H}_{5^{\prime} \mathrm{a}} \mathrm{H}_{5^{\prime} \mathrm{b}}\right) ; \delta_{\mathrm{C}}(100$ $\left.\mathrm{MHz} ; \mathrm{D}_{2} \mathrm{O}\right) 161.2\left(\mathrm{~s}, \mathrm{C}_{4}\right), 151.0\left(\mathrm{~s}, \mathrm{C}_{2}\right), 144.4\left(\mathrm{~s}, \mathrm{C}_{6}\right), 94.7\left(\mathrm{~s}, \mathrm{C}_{5}\right)$, $85.5\left(\mathrm{~s}, \mathrm{C}_{1^{\prime}}\right), 81.5\left(\mathrm{~d}, J_{\mathrm{C}^{\prime}-\mathrm{P}}=9.0 \mathrm{~Hz}, \mathrm{C}_{4^{\prime}}\right), 75.3\left(\mathrm{~s}, \mathrm{C}_{2^{\prime}}\right), 73.5\left(\mathrm{~s}, \mathrm{C}_{3^{\prime}}\right)$, $63.1\left(\mathrm{~d}, J_{\mathrm{C}^{\prime}-\mathrm{P}}=4.0 \mathrm{~Hz}, \mathrm{C}_{5^{\prime}}\right) ; \delta_{\mathrm{P}}\left(121 \mathrm{MHz}, \mathrm{D}_{2} \mathrm{O}\right) 0.45(\mathrm{~s}) ; \mathrm{LC} / \mathrm{MS}$ (ESI) $m / z 322\left(\mathrm{M}-\mathrm{NH}_{4}^{+}\right)$.

1-( $\beta$-D-Arabinofuranosyl)cytosine-5'-diphosphate, ammonium salt 7a: The general procedure was applied to PEG-araCDP 5a $(0.34 \mathrm{~g}, 0.05 \mathrm{mmol})$ and led to a mixture $(55 \mathrm{mg})$ of araCDP and succinamide (ratio: 88/12). An aliquot (10 mg) was dissolved in water $(2 \mathrm{~mL})$ and submitted to dialysis. AraCDP 7a ( $8.50 \mathrm{mg}, 96 \%)$ was obtained as a white solid after freeze-drying. $\lambda_{\max }\left(\mathrm{H}_{2} \mathrm{O}\right) / 274 \mathrm{~nm}\left(\varepsilon / \mathrm{dm}^{3} \mathrm{~mol}^{-1} \mathrm{~cm}^{-1} 7900\right), 246$ (3800); $\delta_{\mathrm{H}}\left(300 \mathrm{MHz} ; \mathrm{D}_{2} \mathrm{O}\right) 7.85\left(\mathrm{~d}, J_{6-5}=7.6 \mathrm{~Hz}, 1 \mathrm{H}, \mathrm{H}_{6}\right), 6.14(\mathrm{~d}$, $\left.J_{1^{\prime}-2^{\prime}}=5.4 \mathrm{~Hz}, 1 \mathrm{H}, \mathrm{H}_{1^{\prime}}\right), 6.03\left(\mathrm{~d}, J_{5-6}=7.6 \mathrm{~Hz}, 1 \mathrm{H}, \mathrm{H}_{5}\right), 4.35$ $\left(\mathrm{pt}, J=5.4 \mathrm{~Hz}, 1 \mathrm{H}, \mathrm{H}_{2^{\prime}}\right), 4.20-4.10\left(\mathrm{~m}, 3 \mathrm{H}, \mathrm{H}_{3^{\prime}} \mathrm{H}_{5^{\prime} \mathrm{a}} \mathrm{H}_{5^{\prime} \mathrm{b}}\right), 4.00$ $\left(\mathrm{m}, 1 \mathrm{H}, \mathrm{H}_{4^{\prime}}\right) ; \delta_{\mathrm{C}}\left(100 \mathrm{MHz} ; \mathrm{D}_{2} \mathrm{O}\right) 166.1\left(\mathrm{~s}, \mathrm{C}_{4}\right), 157.4\left(\mathrm{~s}, \mathrm{C}_{2}\right)$, $142.7\left(\mathrm{~s}, \mathrm{C}_{6}\right), 95.7\left(\mathrm{~s}, \mathrm{C}_{5}\right), 85.1\left(\mathrm{~s}, \mathrm{C}_{1^{\prime}}\right), 81.1\left(\mathrm{~d}, J_{\mathrm{C}^{\prime}-\mathrm{P}}=9.0 \mathrm{~Hz}\right.$, $\left.\mathrm{C}_{4^{\prime}}\right), 75.3\left(\mathrm{~s}, \mathrm{C}_{2^{\prime}}\right), 73.6\left(\mathrm{~s}, \mathrm{C}_{3^{\prime}}\right), 63.6\left(\mathrm{~d}, J_{\mathrm{C}^{\prime}-\mathrm{P}}=5.0 \mathrm{~Hz}, \mathrm{C}_{5^{\prime}}\right) ; \delta_{\mathrm{P}}$ $\left(121 \mathrm{MHz}, \mathrm{D}_{2} \mathrm{O}\right)-10.42\left(\mathrm{~d}, J_{\beta-\alpha}=20.6 \mathrm{~Hz}, \mathrm{P}_{\beta}\right),-11.10$ $\left(\mathrm{d}, J_{\alpha-\beta}=20.6 \mathrm{~Hz}, \mathrm{P}_{\alpha}\right) ; \mathrm{LC} / \mathrm{MS}(\mathrm{ESI}) m / z 402(\mathrm{M}+\mathrm{H}-$ $\left.2 \mathrm{NH}_{4}^{+}\right)$.

1-( $\beta$-D-Arabinofuranosyl $)$ cytosine-5' - triphosphate, ammonium salt 8a: The general procedure was applied to PEG-araCTP 6a $(0.43 \mathrm{~g}, 0.07 \mathrm{mmol})$ and led to a mixture $(68 \mathrm{mg})$ of araCTP and succinamide (ratio: $95 / 5)$. An aliquot $(8.5 \mathrm{mg}$ ) was dissolved in water $(2 \mathrm{~mL})$ and submitted to dialysis. AraCTP 8a $(8 \mathrm{mg}, 92 \%)$ was obtained as a white solid after freeze-drying. $\lambda_{\max }\left(\mathrm{H}_{2} \mathrm{O}\right) / 273$ $\mathrm{nm}\left(\varepsilon / \mathrm{dm}^{3} \mathrm{~mol}^{-1} \mathrm{~cm}^{-1} 8700\right), 246(4500) ; \delta_{\mathrm{H}}\left(300 \mathrm{MHz} ; \mathrm{D}_{2} \mathrm{O}\right)$ $7.85\left(\mathrm{~d}, J_{6-5}=7.6 \mathrm{~Hz}, 1 \mathrm{H}, \mathrm{H}_{6}\right), 6.14\left(\mathrm{~d}, J_{1^{\prime}-2^{\prime}}=5.4 \mathrm{~Hz}, 1 \mathrm{H}, \mathrm{H}_{1^{\prime}}\right)$, $6.04\left(\mathrm{~d}, J_{5-6}=7.6 \mathrm{~Hz}, 1 \mathrm{H}, \mathrm{H}_{5}\right), 4.35\left(\mathrm{pt}, J=5.4 \mathrm{~Hz}, 1 \mathrm{H}, \mathrm{H}_{2^{\prime}}\right)$, 4.20-4.12 (m, 3H, $\left.\mathrm{H}_{3^{\prime}} \mathrm{H}_{5^{\prime} \mathrm{a}} \mathrm{H}_{5^{\prime} \mathrm{b}}\right), 4.01\left(\mathrm{~m}, 1 \mathrm{H}, \mathrm{H}_{4^{\prime}}\right) ; \delta_{\mathrm{C}}(100$ $\left.\mathrm{MHz} ; \mathrm{D}_{2} \mathrm{O}\right) 166.0\left(\mathrm{~s}, \mathrm{C}_{4}\right), 157.3\left(\mathrm{~s}, \mathrm{C}_{2}\right), 142.8\left(\mathrm{~s}, \mathrm{C}_{6}\right), 95.7\left(\mathrm{~s}, \mathrm{C}_{5}\right)$, $85.3\left(\mathrm{~s}, \mathrm{C}_{1^{\prime}}\right), 81.1\left(\mathrm{~d}, J_{\mathrm{C}^{\prime}-\mathrm{P}}=9.0 \mathrm{~Hz}, \mathrm{C}_{4^{\prime}}\right), 75.4\left(\mathrm{~s}, \mathrm{C}_{2^{\prime}}\right)$, $73.6\left(\mathrm{~s}, \mathrm{C}_{3^{\prime}}\right), 64.0\left(\mathrm{~d}, J_{\mathrm{C}^{\prime}-\mathrm{P}}=5.0 \mathrm{~Hz}, \mathrm{C}_{5^{\prime}}\right) ; \delta_{\mathrm{P}}\left(121 \mathrm{MHz}, \mathrm{D}_{2} \mathrm{O}\right)$ $-10.45\left(\mathrm{~d}, J_{\gamma-\beta}=18.2 \mathrm{~Hz}, \mathrm{P}_{\gamma}\right),-11.20\left(\mathrm{~d}, J_{\alpha-\beta}=19.4 \mathrm{~Hz}, \mathrm{P}_{\alpha}\right)$, $-22.96\left(\mathrm{t}, J_{\beta-\gamma}=J_{\beta-\alpha}=18.2 \mathrm{~Hz}, \mathrm{P}_{\beta}\right)$; LC/MS (ESI) $m / z 482$ $\left(\mathrm{M}+2 \mathrm{H}-3 \mathrm{NH}_{4}^{+}\right)$.

Acknowledgment. C.C. is grateful to the French Ministry of Education and Research (MENRT) for a Ph.D. grant and we thank the "Centre National de Recherches Scientifiques" (CNRS) for funding.

Supporting Information Available: General information, experimental details, and characterization data for reported compounds. This material is available free of charge via the Internet at http://pubs.acs.org. 